\title{
Greenwich papers
}

in political economy

\section{Minsky models. A structured survey}

\author{
Maria Nikolaidi \\ University of Greenwich \\ And \\ Engelbert Stockhammer \\ Kingston University
}

\begin{abstract}
Minsky's ideas have recently gained prominence in the mainstream as well as in the heterodox literature. However, there exists no agreement upon the formal presentation of Minsky's insights. The aim of this paper is to survey the literature and identify differences and similarities in the ways through which Minskyan ideas have been formalised. We distinguish between the models that focus on the dynamics of debt or interest, with no or a secondary role for asset prices, and the models in which asset prices play a key role in the dynamic behaviour of the economy. Within the first category of models we make a classification between (i) the Kalecki-Minsky models, (ii) the Kaldor-Minsky models, (iii) the Goodwin-Minsky models, (iv) the credit rationing Minsky models, (v) the endogenous target debt ratio models and (vi) the Minsky-Veblen models. Within the second category of models, we distinguish between (i) the equity price Minsky models and (ii) the real estate price Minsky models. Key limitations of the models and directions for future research are outlined.
\end{abstract}

\author{
Year: 2017 \\ No: GPERC50
}


Keywords: business cycles, financial instability, post-Keynesian economics, debt cycles

Acknowledgments: We thank two anonymous referees for their constructive comments and suggestions. The paper has also benefited from comments by Sébastian Charles, Yannis Dafermos, Giorgos Gouzoulis, Rob Jump, Ewa Karwowski, Yun Kim, Karsten Köhler, Hiroshi Nishi, Soon Ryoo and Bazil Sansom. An earlier version of the paper was presented at Kingston University and has benefited from discussion there. All mistakes are the authors'.

JEL codes: B50, E32, G01

Corresponding author: Maria Nikolaidi, Senior Lecturer in Economics, Greenwich Political Economy Research Centre, University of Greenwich, email: M.Nikolaidi@ greenwich.ac.uk 


\section{Introduction}

Since the global financial crisis there has been a surge in interest in the work of Hyman Minsky and his Financial Instability Hypothesis (FIH). Even the financial press (Financial Times Alphaville 20/8/2007), ${ }^{1}$ the key economic policy institutions (White, 2009; IMF, 2012) and the mainstream economics literature (e.g. Eggertsson and Krugman, 2012 and Bhattacharaya et al., 2015) refer to Minsky respectfully. However, there is a literature on modelling Minsky's FIH within the field of heterodox economics that has been largely ignored by this interest in Minsky. The aim of this paper is to offer a survey of this literature.

Minsky's financial theory of economic crises explains how periods of tranquil growth lead to more financially fragile structures and speculative booms that can result in deep recessions and instability (Minsky, 1975, 1982, 2008 [1986]). In Minsky's theoretical framework financial fragility increases due to endogenous forces that are linked with institutional transformations and the willingness of firms and banks to adopt riskier financial practices because of lower perceived uncertainty. Financial markets play also an important role in the generation of booms and busts since asset prices affect investment and debt relationships. There are at least four key features in Minsky's theory that have been extensively used in the Minskyan models so far. First, the debt ratio of firms tends to increase during the economic boom. Minsky expressed this over-indebtedness via his categorisation of firms into hedge, speculative and Ponzi ones. His FIH suggests that during periods of tranquillity firms gradually shift from hedge to speculative or Ponzi regimes and the financial fragility becomes higher. Second, stock market prices, which tend to increase during economic expansions, have a positive impact on economic activity via his 'two price' theory of investment. Third, the accumulation of debt has generally a negative impact of economic activity. However, this negative impact might take time to materialise because the rise in indebtedness is accompanied by (i) asset price inflation that boosts investment and (ii) a decline in the desired margins of safety of banks and firms that increases credit expansion. Fourth, one of the reasons why economic booms come to an end is the rise in the interest rate that comes from commercial banks' response to the rising indebtedness of borrowers or from central bank's policy to increase interest rates in economic booms.

Minsky's writings are rich and innovative, but lack analytical clarity. Since the mid 1980s there has been a growing number of papers that have tried to give a formal representation of Minsky's arguments. While all Minskyan models share that the financial variables play an important role in generating business cycles or instability, a closer examination reveals substantial differences in the mechanisms involved in the models as well as their dynamic properties. The aim of this paper is to survey the literature and identify differences and similarities in the mechanisms that give rise to business cycles or instability. We suggest a structure to classify Minsky-inspired models. We will use the term Minsky model for macroeconomic models that analyse the dynamic interaction between real and financial variables, build on Minsky and model some of the mechanisms he highlighted. We will distinguish between models that focus on debt or interest dynamics and models in which asset price dynamics play a key role. In the first type of models the source of the dynamics is in the interaction of the goods market with the financial market and the key variable is the debt ratio or the interest rate. Within this category of models we make a classification between (i) the KaleckiMinsky models that assume a stable goods market, (ii) the Kaldor-Minsky models which postulate

\footnotetext{
${ }^{1}$ https://ftalphaville.ft.com/2007/08/20/6687/economist-idol-minskys-new-found-fame/
} 
instability in the goods market, (iii) the Goodwin-Minsky models that incorporate debt dynamics into the traditional Goodwin interactions between the wage share and employment rate, (iv) the credit rationing Minsky models which consider explicitly credit rationing and the role that banks' financial position play in the provision of loans, $(v)$ the endogenous target debt ratio models in which the accumulation of debt is driven by the stock-flow norms of the private sector that change endogenously during the economic cycle and (vi) the Minsky-Veblen models that combine consumer debt with the Veblenian ideas of emulation motives. Within the asset price dynamics models, we distinguish between (i) the equity price Minsky models that analyse the cycles and the instability that arise from the dynamics of equity prices and (ii) the real estate price Minsky models that study the dynamic interaction between mortgages and housing prices.

The paper is structured as follows. Section 2 provides an overview of the Minsky models and describes our suggested classification. Section 3 analyses the details of the Minsky models that concentrate on the debt or interest dynamics. Section 4 scrutinises the Minsky models in which asset prices play a key role. Section 5 discusses mainstream models that have incorporated Minskyan ideas. Section 6 summarises the key differences between the families of Minsky models, outlines their key limitations and briefly identifies directions for future research.

\section{Overview and structure of Minsky models}

There are several dimensions along which there are differences in the Minskyan models. Key differences include: Is the aim of the model to demonstrate the instability of the system or the emergence of endogenous cycles? Is the main source of instability in the interaction of the goods market and financial markets or is the source of the instability the financial sector itself? Is the key financial variable debt, the interest rate or asset prices? Does the interest rate change because of a change in portfolio decision, the behaviour of commercial banks or the policy of the central bank? What is the residual source of finance? Do banks ration credit?

We will refer to Minsky model when authors positively refer to Minsky and offer a formal macroeconomic model in which there are causally related cycles in financial markets and real markets or unstable interactions between the two. Figure 1 summarises our suggested structure of Minsky models. Our broad distinction relies on whether the source of cyclical dynamics and instability is in the interaction between the goods markets and the financial market, with debt or interest rate dynamics being central, or whether it is primarily in the financial markets itself, with asset prices playing the key role. The relevant financial market in the traditional Minsky models is the equity market. However, there are also some Minsky models that pay particular attention to the interaction between housing price and mortgages despite the fact that housing prices are not considered an integral part of Minsky's analysis.

$<$ Figure 1>

The Kalecki-Minsky models constitute the first group of debt or interest dynamics models. Here the output is demand determined, the standard Keynesian stability condition on the goods market holds (marginal propensity to save is larger than the marginal propensity to invest) while asset prices and household debt are assumed away. In these models the debt-to-capital ratio is used as an indicator 
of financial fragility. Also, many of these models (e.g. Lima and Meirelles, 2007; Nishi, 2012; Sasaki and Fujita, 2012) measure the financial fragility of firms by using Minsky's classification of hedge, speculative and Ponzi finance regimes based on the relationship between investment expenditures, profits and interest payments. ${ }^{2}$ In the majority of the Kalecki-Minsky models the interest rate is endogenous. The interest rates are set by commercial banks which increase in response to the rising debt-to-capital ratios of their costumers (e.g. Charles, 2008) or because of increasing economic activity (e.g. Lima and Meirelles, 2007). The labour market is not explicitly analysed in the KaleckiMinsky models (an exception is Fazzari et al., 2008).

The second group within the debt or interest dynamics models are the Kaldor-Minsky models. Kaldor (1940) proposed a model where the goods market is overshooting because of strong accelerator effects. ${ }^{3}$ While in Kaldor and other related literature investment levels out at some point because of real constraints (e.g. supply side bottle necks), the Kaldor-Minsky model "is made unstable by a strong investment accelerator, but the instability is contained by financial forces" (Foley, 1987, p. 364). In most Kaldor-Minsky models the interest rate is endogenous (e.g. Foley, 1987). However, there are also models in which the interest rate is exogenous (e.g. Skott, 1994).

The third group is the Goodwin-Minsky models. Goodwin (1967) examined the cycles that can be generated by the interaction of wage share and employment rate. In his framework the Say's law holds and output is determined by capital stock. In the Goodwin-Minsky models debt is introduced via an investment function and interest payments squeeze profits and investment in the same way that wages do in the Goodwin model. A key difference of the Goodwin-Minsky models from the Kalecki-Minsky and the Kaldor-Minsky models is that labour market plays a central role via the Marxian idea of the reserve army of labour.

The fourth group is the credit rationing Minsky models. In contrast to the previous models, banks in these models apply credit rationing explicitly and this credit rationing is affected by banks' financial position. Credit rationing refers either to the volume of credit that is supplied by banks (Ryoo, 2013b; Nikolaidi, 2014) or to the interest rate that is charged by banks which in turn affects the amount of credit (Delli Gatti et al., 2005, 2010). In these models the interaction between the financial position of firms and the financial position of banks plays a central role in the emergence of cycles and instability.

The fifth group is the endogenous target debt ratio models (Dafermos, 2017; Jump et al., 2017). In these models the expenditures of the private sector and the dynamics of debt are affected by stockflow norms (target debt ratios). These stock-flow norms change endogenously based on the Minskyan argument that the perception of risk alters during the economic cycle: in a period of tranquil or high growth firms, or the private sector in general, increase their target of debt; the opposite is true during period of low or volatile growth. This endogeneity of the target debt ratios is conducive to cycles and instability.

\footnotetext{
2 Foley (2003) was the first one who incorporated the hedge, speculative and Ponzi finance regime classification into an open economy macro model. This classification has also been incorporated into agentbased models (see e.g. Delli Gatti et al., 2003; Chiarella and Di Guilmi, 2011).

${ }^{3}$ The choice of labels for our families is somewhat arbitrary. In particular, Kaldor $(1940$, p. 78$)$ notes that his model is very similar to an earlier paper by Kalecki (1937). We think our labels are reasonably accurate as most Kaleckian models assume or imply stable goods markets (e.g. Lavoie, 2014).
} 
The sixth group is the Minsky-Veblen models. Applying Veblen's (1970 [1899]) ideas about the impact of social conventions on consumption, the Minsky-Veblen models assume that low-income households take on consumer debt in order to increase their consumption expenditures and emulate the high-income households (Kapeller and Schütz, 2014; Ryoo and Kim, 2014; Kapeller et al., 2016). In these models the credit provision is affected by households' balance sheet, which implies that there is credit rationing. The interest rate can be either endogenous or exogenous. Cycles arise because banks are willing to provide credit to low-income households when their indebtedness is low, but reduce credit availability once households' interest payments have become sufficiently high.

Within the group of asset price dynamics models the first type is the equity price Minsky models. In these models households invest in different financial assets, including equities, and their portfolio choice affects the equity price dynamics. The expected rate of return on equity plays a key role in generating instability or endogenous cycles (see e.g. Taylor and O'Connell, 1985; Ryoo 2010, 2013a; Chiarella and Di Guilmi, 2011). When the expected rate of return increases, the price of equities goes up and this affects positively economic activity via investment and/or consumption. The second type of asset price models are the real estate price Minsky models. These models have been motivated by the global financial crisis and focus on the role of housing prices in the emergence of instability and cycles (Ryoo, 2016). House prices affect the provision of mortgages (since houses are used as collateral in the debt contracts). As mortgages increase, the demand for houses increases leading to further increases in the price of houses. As in the Minsky-Veblen models, the boom stops because of the rise in household indebtedness.

Table 1 gives an overview of the various features of the papers covered in this survey. These features include (i) the overshooting or not of the goods market with respect to demand shocks, (ii) the existence of a Keynesian or a non-Keynesian goods market, (iii) the incorporation of household debt or corporate debt, (iv) the inclusion or not of equity or real estate prices, (v) the explicit incorporation or not of credit rationing, (vi) the examination or not of the labour market, (vii) the inclusion of an endogenous or exogenous interest rate and (viii) the incorporation of endogenous stock-flow norms).

Table 1 shows that the models also differ in the type of analytical framework that they use and the dynamic analysis that they conduct. The early Minsky models were primarily small structural models with 2 or 3 dynamic variables, such as the leverage of firms, the investment rate and the interest rate. The most recent models tend to be stock-flow consistent (SFC) with more complex and explicit financial structures. There are also some attempts to develop Minskyan agent-based models (ABM). These models analyse financial fragility via the interaction between individual firms and banks, placing emphasis on network effects, or allow heterogenous firms to have different strategies or balance sheet structures. While some models concentrate more on the conditions under which local instability can arise, other models pay their attention to the emergence of cycles which in many cases arise when the equilibrium points are locally unstable but global stability exists because of bounded functions.

$<$ Table 1> 


\section{Debt or interest dynamics}

\subsection{Kalecki-Minsky models}

In the Kalecki-Minsky models the investment decisions of firms are captured by a Kaleckian investment function in which the rate of profit plays a key role. If the retained profits are not sufficient to cover the investment expenditures, firms demand bank loans which are always supplied (i.e. there is no explicit credit rationing). The debt ratio has negative effects on investment because it increases the interest payments of firms. Output is demand-determined and the marginal propensity to save is higher than the marginal propensity to invest, ensuring goods market equilibrium. Typically, there are two types of households: rentiers who save a proportion of their income and workers who consume all their income. There is no equity market and therefore asset prices are assumed away.

Lima and Meirelles (2007), Charles (2008), Fazzari et al. (2008) and Nishi (2012) have developed the most prominent recent Kalecki-Minsky models. These models draw to a great extent on the models developed by Jarsulic (1990), Dutt (1995) and Lavoie (1995) which were the first models that incorporated debt and finance into the Kaleckian framework. In our review we focus on the most recent models that pay more explicit attention to Minskyan dynamics. It is important to note that, with the exception of Fazzari et al. (2008), these models do not analyse cycles: they only focus on the conditions under which stability or instability arises. In addition, in many of these models the categorisation into hedge, speculative and Ponzi units is used and it is shown that instability is mostly associated with the speculative and Ponzi finance structures. Lastly, all the Kalecki-Minsky models are small structural models.

Our analysis will start with the models that consider that the interest rate changes in an endogenous way either because of commercial bank decisions (Lima and Meirelles, 2007; Charles, 2008), or because of changes in inflation that are passed on to the nominal interest rate (Fazzari et al. 2008). Then we will analyse Nishi's (2012) model where the interest rate is considered exogenous.

Charles (2008) develops a Minsky model that is composed of firms, households and banks. Firms produce a single good that is used for consumption and investment purposes. Investment is financed via bank loans and retained profits. Equities are assumed away. There are two types of households: rentiers who save a proportion of their income and wealth and workers who consume all their income. Banks provide loans to firms on demand. Output is demand-determined. Commercial banks change the interest rates according to the indebtedness of firms.

Firms' desired investment rate $\left(g^{d}\right)$ depends on animal spirits $(\alpha)$, the gross rate of profit $(r)$ and the interest payments on accumulated debt. In particular, we have:

$$
g d=\alpha+\beta(r-i d)
$$

where $i$ is the interest rate and $d$ is the ratio of firms' debt $(D)$ to capital $(K) . \beta$ is a positive parameter that captures the sensitivity of the investment rate to the net profit rate (which is equal to the gross rate of profit minus the interest payments to capital ratio).

The net borrowing of firms $(\dot{D})$ is derived from firms' budget constraint. Thus, it is equal to investment $(I)$ minus net retained profits: 
$\dot{D}=I-s_{f}(R-i D)$

where $s_{f}$ is the retention rate and $R$ are the gross profits. Dividing through by capital stock, we get:

$\frac{\dot{D}}{K}=g-s_{f}(r-i d)$

where $g$ is the effective investment rate.

Rentiers receive distributed profits of firms and interest income on deposits. The total saving of the economy is equal to the saving of firms plus the saving of rentiers. Hence, the ratio of saving to capital stock $(g s)$ is given by:

$g s=s_{f}(r-i d)+s_{c}\left(\left(1-s_{f}\right)(r-i d)+i d\right)$

where $s_{c}$ is the capitalists' propensity to save out of their dividend income and interest on deposits.

Charles (2008) makes a distinction between the desired and the effective investment rate and assumes that the effective investment rate adjusts towards the desired one via the following formula:

$\dot{g}=\lambda(g d-g)$

where $\lambda>0$ is the adjustment speed.

Differentiating the debt-to-capital ratio, we get the law of motion of $d$ :

$\dot{d}=\frac{\dot{D}}{K}-g d$

The interest rate is an increasing function of debt-to-capital ratio:

$i=\bar{i}+\phi d$

where $\bar{i}$ and $\phi$ are positive parameters. The assumption is that a higher debt-to-capital ratio increases perceived risk, inducing banks to increase the interest rate in order to compensate for this risk.

An increase in the debt-to-capital ratio has both positive and negative effects on effective investment rate. On the one hand, a higher debt-to-capital ratio tends to increase consumption (and thus capacity utilisation and profit rate) since the rise in the interest payments overcompensates the decline in distributed profits, leading to higher rentier consumption. On the other hand, a higher debt-to-capital ratio tends to reduce the profit rate since firms have to pay higher interest. In Charles (2008) the adverse effects on investment overcompensate the positive ones and thus investment is debt-burdened.

The 2D system of the model consists of the debt-to-capital ratio and the investment rate. Combining the debt-to-capital ratio with equation (7) we get an isocline that is quadratic in $d$. In a $g-d$ 
diagram the isocline is U-shaped. Hence, we get two equilibrium points. The first equilibrium point is stable and is characterised by high investment rate and low debt-to-capital ratio. The second equilibrium point is a saddle point and exhibits a low investment rate and a high debt-to-capital ratio. Charles (2008) tries to connect the equilibrium points with the finance regimes of Minsky: the stable point resembles a hedge finance structure while the saddle point is closer to the speculative or Ponzi finance structure.

Lima and Meirelles (2007) construct a macrodynamic model which is similar to the model of Charles (2008). There are two crucial differences. The first difference is that the authors formalise the hedge, speculative and Ponzi regime and use it in their dynamic analysis. ${ }^{4}$ The second difference is that the authors assume an endogenous interest rate that depends on economic activity and not on the leverage ratio. ${ }^{5}$ In particular, in their model the law of motion of the interest rate is a function of the banking mark-up, which in turn depends on economic activity. The change in the interest is given by:

$\dot{i}=\bar{i} \theta(u-\bar{u})$

where $\bar{i}$ is the base interest rate set by the central bank, $\theta$ is the responsiveness of the banking mark-up to capacity utilisation, $u$ is the capacity utilisation and $\bar{u}$ is a threshold value for the capacity utilisation. Lima and Meirelles (2007) consider both the case in which interest rate is procyclical $(\theta>0)$ and the case in which it is counter-cyclical $(\theta<0)$. The commercial banks change the interest rate if economic activity is higher (lower) than the threshold value.

The 2D system of the model consists of the debt-to-capital ratio and the interest rate captured by equations (6) and (8). The authors identify the hedge, speculative and Ponzi finance regime areas in the $i-g$ diagram. The system has one equilibrium point and its stability properties depend on the finance regime in which it is located. If it is located in the hedge finance area, the equilibrium point is stable when the banking mark-up is pro-cyclical and the growth rate is higher than the interest rate. When the banking mark-up is counter-cyclical, the equilibrium is unstable irrespective of the other conditions. If the equilibrium point is located in the speculative finance area, it is unstable when the propensity to save of capitalists is sufficiently low. When this propensity is high enough, stability will arise only if banking mark-up is pro-cyclical and the growth rate is higher than the interest rate. Finally, within a Ponzi regime the equilibrium point is always unstable.

Fazzari et al. (2008) present a richer model that combines an investment function, which incorporates debt payments effects and an accelerator effect, with a non-linear Phillips curve. One key difference of their model with the other Kalecki-Minsky models is that the nominal interest rate increases when inflation goes up (the implicit assumption seems to be that the central bank has a

\footnotetext{
${ }^{4}$ The distinction between hedge and speculative units relies on the comparison between the gross profits and the sum of investment expenditures and interest payments. When the former is higher than the latter, we have a hedge regime while, when the opposite holds, we have a speculative regime. In the extreme case where the gross profits are lower than the interest payments, we have a Ponzi regime.

${ }^{5}$ There are some additional minor differences. In Lima and Meirelles' set up the desired investment rate of firms depends on the interest rate and not on the interest payments on debt, a separate sensitivity to gross profits and interest rate is assumed, rentiers' propensities to save out of interest and dividends are different and investment is debt-led (although in the dynamic analysis the investment rate is allowed to be debt-neutral by equalising the propensities to save out of interest and dividends).
} 
real interest target which is fixed). Since inflation is a negative function of unemployment rate, it turns out that the nominal interest rate depends positively on economic activity.

Investment depends on output, via an accelerator mechanism, as well as the expected real cash flow of firms. It is assumed that there are two types of consumers: the forward-looking and backwardlooking ones. The forward-looking consumers base their consumption on the expected income while the backward-looking ones consume based on the income of the previous period. Overall, an increase in economic activity increases the disposable income of households, leading to higher consumption. Firms take on debt in order to finance the difference between investment and cash flow. It is implicitly assumed that the saving rate of firms is equal to 1 . The net borrowing of firms is determined in a similar way as in equation (2). The authors use a sophisticated version of the Phillips curve that assumes that wage inflation depends on productivity growth and the level as well as the change in unemployment, allowing thereby for unemployment hysteresis. Prices are determined via a mark-up over the unit labour costs and thus wage inflation directly affects price inflation.

The model has a complex and non-linear dynamic structure and the authors thus resort to simulations based on empirically motivated parameters in order to investigate its properties. They show that in their benchmark simulations the system produces cycles after a positive demand shock. Initially, investment increases and gradually the debt ratio starts becoming higher. Simultaneously, higher economic activity leads to lower unemployment. This causes a rise in inflation (via the Phillips curve) which in turn leads to a rise in the nominal interest rate. The resulting increase in the debt service is the reason why the boom terminates at some point in time. The decline in economic activity ultimately leads to a reduction in the interest rate that makes the debt service lower, allowing the economy to recover. Fazzari et al. (2008) point out that, although the produced cycles eventually die out, they persist for a long period of time. They also illustrate that the responsiveness of the investment rate to the cash flow is one of the key parameters that affect the dynamic properties of their model. When this responsiveness increases, the amplitude of the cycles becomes higher; also, when the responsiveness becomes sufficiently high, the system produces asymptotic instability.

We now turn to the model of Nishi (2012) who assumes that the interest rate is exogenous. The structure of his model is very similar to the structure of Charles' (2008) model. A key difference is that in Nishi's investment function the desired investment rate depends on the gross rate of profit and the interest payments separately, making it possible to get either a debt-burdened or a debt-led investment regime.

Nishi (2012) uses his model to examine how the various Minskyan finance regimes (hedge, speculative and Ponzi) can arise under different investment regimes. ${ }^{6}$ His discussion has a more long-term focus and effectively uses the finance regimes to discuss different levels of the (fixed) interest rate. He shows that when the interest rate is low we may have a hedge and speculative regime. When these non-Ponzi regimes are combined with a debt-burdened growth regime the equilibrium point is stable. However, if the non-Ponzi regimes are combined with a debt-led growth

\footnotetext{
${ }^{6}$ Nishi's (2012) distinction between hedge and speculative regimes relies on the comparison of gross profits with net borrowing and interest payments. This allows hedge units to borrow, which is not the case in Lima and Meirelles (2007) where hedge units do not borrow. The Ponzi regime is defined as in Lima and Meirelles (2007).
} 
regime, we may have an unstable equilibrium point. When the interest rate is sufficiently high there is the possibility of a Ponzi regime. If the Ponzi regime is combined with a debt-led growth regime we always have instability.

It is worth pointing out here that in the Kalecki-Minsky models presented above the leverage ratio turns out to be pro-cyclical in most cases. However, Lavoie and Seccareccia (2001) have argued that the Kaleckian framework does not in general generate a pro-cyclical leverage ratio, because investment creates profits. Thus while in the boom individual firms might want to take on more debt, the boom conditions make profits high and firms can finance investment internally. This is also referred to as the paradox of debt. ${ }^{7}$ Charles (2016) has shown that in a Kalecki-Minsky model the counter-cyclicality of the leverage ratio is less likely when the retention rate of firms is low. A low retention rate reduces the ability of firms to finance investment internally during economic expansion.

To sum up, in the Kalecki-Minsky models debt is accumulated as firms demand bank loans in order to finance their desired investment expenditures. In most of these models the accumulation of debt has negative feedback effects on investment either directly (debt-burdened regime) or because of the fact that a higher debt ratio increases the interest rate (Charles, 2008). In some Kaleckin-Minsky models the interest rate can also increase when there is higher economic activity that induces commercial banks to increase their banking mark-up (Lima and Meirelles, 2007) or when central banks increase the base interest rate due to higher inflation (Fazzari et al., 2008).

\subsection{Kaldor-Minsky models}

In Kaldor-Minsky models firms' investment expenditures are positively affected by economic activity (either through the rate of profit or through the capacity utilisation) and are negatively or positively affected by the accumulation of debt. Similar to the Kalecki-Minsky models output is demand determined, loans are provided on demand (i.e. there is no explicit credit rationing) and there is no equity market. The hall mark of the Kaldor-Minsky model is that investment is overshooting. In contrast to the Kalecki-Minsky models, there is an unstable goods market: the marginal propensity to save is lower than the marginal propensity to invest (close to the equilibrium). This is a characteristic of the Kaldor models (see e.g. Chiarella et al., 2000) that draw on Kaldor's (1940) trade cycle model in which the marginal propensity to save is lower than the marginal propensity to invest at intermediate levels of output.

Asada (2001) develops a highly stylised Kaldor-Minsky model where Minsky cycles can be produced. The author gives more emphasis to the assumptions that are needed to produce cycles while less attention is paid to the economic intuition of the macroeconomic model. The structure of Asada's model is similar to the structure of Kalecki-Minsky models. His investment function can be written as follows:

$$
g d=\Phi\left(r, d, i, s_{f}\right)
$$

\footnotetext{
7 Lavoie $(2014$, p. 448) argues that when debt-led demand is combined with a counter-cyclical debt ratio, which he refers to as a 'Steindl regime', cycles can arise that work in the opposite direction of Minsky cycles.
} 
where $\Phi_{r}=\partial \Phi / \partial r>0, \Phi_{d}=\partial \Phi / \partial d<0, \Phi_{i}=\partial \Phi / \partial i<0$ and $\Phi_{s f}=\partial \Phi / \partial s_{f}>0$.

The saving rate is given by:

$$
g s=s_{f}(r-i d)+s_{c}\left(\left(1-s_{f}\right)(r-i d)+i d+\varepsilon d\right)
$$

This saving function is similar to the saving function of Charles (2008). The main difference is that Asada includes a positive impact of a safe asset on saving. This safe asset is assumed to be a linear function of the debt-to-capital ratio, i.e. it is equal to $\varepsilon d$. Therefore, equation (10) implies that an increase in the debt-to-capital ratio has both positive and negative effects on the saving rate. A higher $\varepsilon$ reinforces the positive effect of the debt ratio on the saving rate.

The interest rate is a positive function of the debt-to-capital ratio as in Charles (2008). The outputto-capital ratio increases when the sum of consumption-to-capital ratio and desired investment rate is higher than the current output-to-capital ratio:

$$
\dot{y}=\sigma\left(c+g_{d}-y\right)
$$

where $y=Y / K$ is the output-to-capital ratio, $c=C / K$ is the consumption-to-capital ratio and $\sigma$ is a positive adjustment parameter.

The debt-to-capital ratio and the output-to-capital ratio constitute the 2D system of the model, captured by equations (6) and (11) respectively. Asada (2001) assumes, without much explanation, that the goods market is de-stabilising, the output is debt-burdened, the leverage ratio is pro-cyclical and the debt ratio is self-stabilising.

Asada uses the Hopf bifurcation theorem in order to show the conditions under which a limit cycle arises. How does the cycle behave in this model? Suppose that the economy is initially characterised by a low output-to-capital ratio and a low debt-to-capital ratio. Since the debt-to-capital ratio is sufficiently low, the investment rate gradually becomes higher. When investment and output have become sufficiently high, the debt-to-capital ratio starts increasing. At some point, this increasing debt-to-capital ratio causes a decline in the investment rate and thus in output-to-capital ratio. Once the investment rate has become sufficiently low, the debt-to-capital ratio decreases and the economy enters into a new expansionary period.

Semmler (1987) has developed another model with Kaldor-Minsky features. He introduces financial variables into a profit-investment dynamic system where the saving function is S-shaped as in Kaldor. The system without the financial variables produces a limit cycle. In the system with the financial variables the interest rate and the debt payment commitments have a negative impact on investment (i.e. investment is debt-burdened) and the debt-to-capital ratio rises during the expansions (i.e. leverage is pro-cyclical). The introduction of the financial variables can reduce the amplitude of the limit cycle (i.e. expansions become shorter and contractions become less severe) or can increase the possibility of instability.

Two other Kaldor-Minsky models are those developed by Foley (1987) and Jarsulic (1989) in which the interest rate plays a key role in the emergence of the cycles. In Foley's model a decline in the interest rate increases borrowing which in turn increases investment and profitability. However, higher demand for credit produces a rise in the interest rate (via a loanable funds market) which has 
a negative impact on borrowing. Foley (1987) uses the Hopf bifurcation theorem in order to show the emergence of cycles. Jarsulic's (1989) model generates some similar dynamics. He postulates an investment function where the investment rate depends negatively on the interest rate and he also assumes that a higher investment rate increases the interest rate. His investment function is nonlinear: he assumes that the investment rate starts declining when it is already high. As a result, his 2D dynamic system is bounded which allows him to use the Poincaré-Bendixson theorem to show the emergence of a limit cycle.

Skott (1994) develops a Kaldorian model in which some abstract financial variables are introduced in the investment function. In particular, he uses a financial fragility variable $(F)$ and a tranquillity variable $(T)$. The financial fragility variable captures the sensitivity of the financial system to small disturbances that might affect the ability of economic units to fulfil their financial obligations. As a proxy of financial fragility, Skott (1994) uses the ratio of interest payments to the normal rate of profit ( $F=i d / \bar{r}$ ). As he points out, "Fragility and tranquillity evolve endogenously and, in accordance with Minsky's behavioural assumptions, it is assumed that changes in fragility depend on the degree of tranquillity: in the absence of financial difficulties agents adopt schemes of increasing optimism" (Skott, 1994, p. 53). Therefore, the change in the financial fragility ratio is given by:

$$
\dot{F}=T
$$

The tranquillity variable is associated with the appearance or not of crises. When a system experiences a crisis, tranquillity is at its minimum value since default and bankruptcy rates are high. Tranquillity is at its maximum value when the financial system functions without disruptions and economic activity is high. As Skott (1994, p. 53) explains, "financial difficulties develop as a result of an incongruence between the optimism which motivated financial arrangements and the actual outcome. If the source of potential instability is located primarily in the business sector (...) then $T$ should depend on financial fragility (inversely) and on realized profit rates (positively)". Hence, he assumes that $T$ is a negative function of $F$ and a positive function of output-to-capital ratio:

$$
T=A y-B F
$$

The investment function is written as:

$$
g_{d}=\Lambda(y)+\varsigma F+\gamma T
$$

where $\Lambda(y)$ is a function where $\Lambda_{y}=\partial \Lambda(y) / \partial y>0$. Similarly to the Kalecki-Minsky models, an increase in economic activity increases investment. However, following Kaldor, it is assumed that investment is an S-shaped function, which implies that the investment rate is bounded (it stops increasing as output-to-capital ratio becomes too high). In addition, investment is positively or negatively affected by financial fragility (i.e. $\varsigma$ can be positive or negative) and is positively affected by the tranquillity indicator $(\gamma>0)$. Since $F=i d / \bar{r}$ and $T=A u-B F$, equation (14) can be rewritten as follows:

$$
g_{d}=\Lambda(y)+\gamma A y+(\varsigma-\gamma B) \frac{i d}{\bar{r}}
$$


where $\bar{r}$ is the normal profit rate while $A$ and $B$ are positive parameters. Equation (15) implies that an increase in economic activity positively affects the investment rate while the interest payments on debt may have a positive or a negative effect on the investment rate. Saving is a function of output and output adjusts to the difference between investment and saving via an equation which is similar to equation (11) used by Asada (2001).

The fragility ratio and the output-to-capital ratio constitute the 2D system. Skott (1994) analyses the stability conditions for this 2D system by considering two cases. In the first case, the impact of financial fragility on investment is positive. It is shown that in this case the model can be stable or unstable and does not produce cycles. In the second case, the impact of financial fragility on investment is negative. This makes it possible to generate cycles which are similar to the cycles generated by the model of Asada (2001). Since Skott's system is bounded due to the S-shaped investment function, he uses the Poincaré-Bendixson theorem to illustrate the conditions under which a limit cycle emerges. According to this theorem, a 2D system that is locally unstable, bounded and has a unique stationary point produces a limit cycle.

To summarise, most Kaldor-Minsky models have a similar structure with the Kalecki-Minsky models. However, in the Kaldor-Minsky models the main source of instability is the accelerator mechanism that is included in the investment function and renders the goods market unstable. Compared to the Kalecki-Minsky models, the analysis of the Kaldor-Minsky models pays more attention to the conditions under which cycles emerge. In some Kaldor-Minsky models the interest rate is exogenous (e.g. Skott, 1994), while in other models the endogenous change in the interest rate is a key part of the cyclical behaviour (e.g. Foley, 1987 and Jarsulic, 1989).

\subsection{Goodwin-Minsky models}

Keen (1995) develops a Goodwin model with some Minskyan features that operate through the wage share equation: a higher debt ratio dampens investment and employment, which affects the wage share, which in turn affects the debt ratio. The use of the Goodwin framework implies that these models treat the labour market explicitly. This is a distinct feature compared to most other Minsky models in which labour market dynamics are absent.

Keen (1995) assumes full capital utilisation and, as a result, output is determined by capital stock, which is driven by the past investment decisions of capitalists. This comes in contrast to the KaleckiMinsky and Kaldor-Minsky models where output is demand-determined. Keen (1995) extends the Goodwin model to include banks, whose rising income share can squeeze industrial profits similar to how a rising wage share squeezes profits. Unlike the Goodwin model, where all profits are reinvested, Keen (1995) uses a non-linear (convex) investment function, which creates a pro-cyclical debt ratio. The interest rate is a positive function of the debt ratio. The theoretical problem of this model is that it does not offer a mechanism that equilibrates investment and saving. ${ }^{8}$

\footnotetext{
${ }^{8}$ The Keynesian mechanism of equilibrating investment and saving is blocked because Say's law is assumed to hold; the classical mechanism is blocked because the interest rate does not clear the market for loanable funds but is determined by the leverage ratio.
} 
The gross investment rate (i.e. net investment rate plus depreciation rate) depends on the net profit rate of firms:

$$
g=P(r-i d)
$$

where $P$ is a convex function of the net profit rate. We have that $r-i d=\pi / v$ where $v$ is the capitaloutput ratio, $\pi=1-\omega-b$ is the profit share, $\omega$ is the wage share and $b=i D / Y$ is the bankers' income share. This means that the gross investment rate ends up being a positive function of the profit share. The convexity of the investment function implies that the profit share has a gradually higher effect on the investment rate. In particular, for relatively low values of the profit share, investment is equal to profits but for relatively high values of the profit share investment becomes higher than profits, which means that the accumulation of debt accelerates.

As in Goodwin's model, the wage share changes in an endogenous way. Since $\omega=w / x$, the change in the wage share is:

$\dot{\omega}=(\Theta(l)-\chi) \omega$

where $\Theta$ is a non-linear positive function of the employment rate $(l), \chi$ is the growth rate of labour productivity, $w$ is the wage rate and $x$ is the labour productivity. When the employment rate becomes higher, the wage share increases.

Since the employment rate is $l=Y / x N$, the law of motion of $l$ is:

$i=(g-\chi-\tau) l$

where $\tau$ is the growth rate of labour force and $N$ is the labour force.

The net borrowing of firms depends on the difference between the investment rate and net profits. Keen (1995) normalises debt by dividing it by output and assumes that firm retain all their profits. In similar lines with Charles (2008), the interest rate is an increasing function of the indebtedness of firms (Keen uses the debt-to-output ratio instead of the debt-to-capital ratio).

The 3D system consists of the wage share and the employment, as in the Goodwin model, as well as the debt-to-capital ratio. Keen (1995) does not offer an analytical solution of the model, but moves swiftly to simulation. ${ }^{9}$ Thus the paper is more effective in illustrating the instabilities that can arise rather than clarifying the properties of the model. In his simulations Keen (1995) shows that both stability and instability can arise in his dynamic system. Instability arises when the base interest rate is high and/or when the interest rate is low and the sensitivity of the interest rate to the debt-tocapital is high. The system breaks down because the rate of profit becomes negative primarily because of increasing firms' interest payments. Keen shows that a break down is prevented when counter-cyclical fiscal policy is introduced. However, in his simulations fiscal policy does not eliminate cycles. Keen (2013) extends the model described above by including an explicit banking sector, endogenous money creation and a more explicit financial structure based on the SFC approach.

\footnotetext{
${ }^{9}$ Such an analytical solution is provided by Grasselli and Costa Lima (2012).
} 
Sordi and Vercelli (2014) argue that Keen (1995) does not take into account that the goods market may be in a disequilibrium and they use an output adjustment mechanism. They propose a model based on Goodwin (1951) flexible accelerator. Therefore, in contrast to Keen (1995), output is demand determined and investment is demand driven (without direct effect of profitability or debt). In our classification it is thus closer to the Kaldor-Minsky model. They derive a 4D system with the wage share, the employment rate, the debt-to-capital ratio and the capital-to-output ratio as state variables and use the Hopf-bifurcation theorem to prove the possibility of cycles. Instability in their model is more likely when investment responds strongly to expected output.

Stockhammer and Michell (2017) demonstrate that pseudo-Goodwin cycles can arise from a Minsky model that is paired with a reserve-army distribution function. Unlike the Goodwin-Minsky model, in their model output is demand determined and demand is debt-burdened and wage-led. The cycles are Minskyan debt cycles and income distribution fluctuates as it is dragged along by the business cycles. The economy thus exhibits pseudo-Goodwin cycles.

\subsection{Credit rationing Minsky models}

A key feature of the Minskyan models presented above is that banks play a relatively passive role. Although in some of these models banks increase the interest rate when the debt ratio of firms increases (e.g. Charles, 2008) or banks are in some cases implicitly considered to co-determine the accumulation of debt, there is no explicit credit rationing based on the financial position of banks. This is at odds with Minsky who has argued that banks are active players in the emergence of financial fragility and credit expansion relies on their financial structure (e.g. Minsky, 2008 [1986], p. 265). The models of Ryoo (2013b), Nikolaidi (2014) and Delli Gatti et al. $(2005,2010)$ belong to the credit rationing Minsky models. ${ }^{10}$

Ryoo (2013b) develops an SFC model that consists of firms, households and banks. Firms take on debt and issue equities in order to externally finance their investment. Equity is the residual source of finance ${ }^{11}$ and the equity-to-deposits ratio in the household portfolio choice is assumed to be constant. This implies that the price of equities needs to adjust in order to keep the ratio constant. Banks provide loans taking into account the profit-to-interest payment ratio and the profitability of banks. The bank capital ratio positively depends on the profitability of firms.

Ryoo (2013b) distinguishes between short cycles and long waves. Based on Skott (1989), the short cycles result from the interaction between destabilising goods market dynamics à la Kaldor and stabilising labour market dynamics. Investment depends on capacity utilisation and there is an explicit function for economic growth whereby growth is affected positively by the profit share and negatively by the employment rate. The profit share is increasing in capacity utilisation. As capacity utilisation increases growth rate responds strongly. The increase in growth rate increases

\footnotetext{
10 The impact of banks' financial position on credit rationing is taken into account in the recent model of Kapeller et al. (2016). However, their model analyses household debt while our credit rationing Minsky models refer exclusively to corporate debt.

${ }^{11}$ Ryoo (2010) supports this assumption by presenting some evidence that the ratio of issues of equity to investment is very volatile and argues that this volatility is better captured when equity emission is modelled as a buffer.
} 
employment. When employment becomes sufficiently high it exerts a negative impact on economic growth, allowing the emergence of cycles.

The long wave of the model is captured by a 2D system which has the leverage ratios of firms and banks as state variables. It is shown that instability is more likely as the responsiveness of credit availability to bank profits increases. Using the Poincaré-Bendixson theorem, it is shown that cycles arise when the system becomes locally unstable. The rationale of the cycle is as follows. When the leverage ratio of firms and banks is low, the debt-to-capital ratio starts increasing because firms are considered to be creditworthy and, hence, more loans are provided by banks. As loans expand, the leverage of banks, which goes hand in hand with bank profitability, goes up. This enhances credit supply. However, when the leverage of firms becomes sufficiently high, firms start being considered less creditworthy. This causes a reduction in credit supply, which in turn leads to a decline in bank leverage and bank profitability which reinforces the decline in credit. The reduction in credit leads to a lower firm leverage. When the leverage ratios of both firms and banks have become sufficiently low, credit starts increasing again and a new cycle begins.

Ryoo (2013b) suggests that instability in his model can be reduced if a financial regulation rule is adopted according to which banks adjust their retention rate in order to achieve a specific leverage ratio. This rule relies on Minsky's writings about the ways through which banking instability can be reduced (see Minsky, 2008 [1986], ch. 13).

Nikolaidi (2014) develops an SFC model with firms, households, banks, government and a central bank. Both firms and banks have a target leverage ratio which captures their desired margins of safety that are deemed to change in an endogenous way: when economic activity is high (low), the target leverage ratios increase (decrease). The target leverage ratio of firms affects their desired investment. The higher the target leverage ratio of firms compared to the actual ratio, the higher their investment, ceteris paribus. Banks provide only a proportion of the loans demanded. They are more willing to reduce credit rationing when their leverage ratio is lower than the target one. Firms take on debt to finance their desired investment which is negatively affected by the leverage ratio of firms. Since there is credit rationing the effective investment is lower than the desired investment. Banks' credit rationing is affected by their leverage ratio and the leverage ratio of firms. ${ }^{12}$ Therefore, in boom periods both the desired investment and the provision of loans become gradually higher, which might lead to instability. The opposite holds in bust periods. Instability is more likely when the target leverage ratios respond strongly to changes in economic activity.

The model can produce cycles (this is shown using the Hopf-bifurcation theorem). The cycles can be described as follows. When investment activity is sufficiently high, the target leverage ratios of both firms and banks increase, leading to higher desired investment and lower credit rationing. This increases debt accumulation and the actual leverage ratios. However, once the leverage ratios have become sufficiently high, both firms and banks become less willing to participate in new debt contracts and economic activity starts slowing down. The decline in economic activity makes the leverage ratios lower and, at the same time, reduces the target leverage ratios of firms and banks reinforcing the contractionary forces. A new boom starts when the leverage ratios have declined

\footnotetext{
12 The formulation of credit rationing draws on the SFC model of Le Heron and Mouakil (2008) who, in line with Minsky, assume that credit rationing depends both on borrower's and lender's risk.
} 
sufficiently. Nikolaidi (2014) also examines the role of fiscal policy. It is shown that counter-cyclical fiscal policy can reduce the instability that stems from the behaviours of firms and banks.

While most of the literature on Minsky uses small or large scale macro models, there is also a family that emphasises heterogeneity among firms and uses agent-based modelling techniques. Delli Gatti et al. $(2005,2010)$ have developed such models with heterogeneous firms and/or heterogeneous banks. Theoretically these models draw on the financial accelerator argument that the availability of credit for firms depends on their net worth (Bernanke and Gertler, 1990; Greenwald and Stiglitz, 1993). However, in line with the credit rationing models discussed above, the credit conditions are also affected by the net worth of banks. In particular, the interest rate depends on the financial position of both firms and banks. Bankruptcy is explicitly introduced (which is an innovation compared to most Minsky models). When a firm goes bankrupt, this affects adversely the net worth of banks, leading to a higher interest rate. This in turn reduces the net worth of firms. Following stylised facts, firm size obeys a power law. This highly skewed distribution implies that idiosyncratic shocks can turn into macro shocks (if they affect one of the few very large firms). This is compounded by network effects that can cause bankruptcy cascades. It is worth mentioning that there is no aggregate demand function comparable to those of most previously discussed models, but output is determined by the optimising behaviour of credit and net worth constrained firms. Unlike many of the models discussed in this survey the main aim is not to analyse endogenous cycles but the conditions under which random shocks can turn into systemic crises. In some ways the models are closer to the New Keynesian financial accelerator approach, but they also highlight Minskyan features.

To sum up, in credit rationing Minsky models cycles and instability are affected by the behaviour and the financial position of banks. In some models the interest rate is exogenous and banks affect the volume of credit directly (Ryoo, 2013b; Nikolaidi, 2014) while in other models the interest rate is a function of the financial position of firms and banks (Delli Gatti et al., 2005, 2010). Banks contribute to the increase in financial fragility during the boom periods by increasing credit availability and/or providing credit at favourable terms. They can reinforce the destabilising forces in the bust period since their financial soundness is affected by macroeconomic performance and this has feedback effects on credit conditions.

\subsection{Endogenous target debt ratio models}

In the endogenous target debt ratio models, firms, banks or the private sector in general have targets about their leverage ratios. These targets are also called stock-flow norms (based on Godley) or desired margins of safety (based on Minsky). The target debt ratios tend to increase when economic and financial performance is good and they tend to decline when economic and financial environment is perceived to be unfavourable and unstable. Higher target debt ratios increase desired investment or desired consumption and tend to reduce credit rationing. In the endogenous target debt ratio models output is demand determined, the interest rate is exogenous and there is no consideration of the labour market.

The model of Nikolaidi (2014), described in the previous section, was the first model that used explicitly an endogenous target debt ratio. Dafermos (2017) incorporated this idea of an endogenous 
target debt ratio into a Godleyan analytical framework. Following Godley's projection analysis (e.g. Godley, 1999), his model consists of three sectors: the private sector (which is consolidated), the government sector and the foreign sector. The balances and the debt of these sectors are explicitly interrelated via Godley's financial balances approach. The private sector has a stock-flow norm (the target net debt-to-income ratio) which is allowed to change endogenously based on the Minskyan idea that the perception of risk and, hence, the desired margins of safety change during the economic cycle.

In his dynamic analysis he first analyses a system with the propensity to spend of the private sector and the private debt-to-income ratio as state variables. In this system the propensity to spend of the private sector increases (decreases) when the target debt-to-income ratio is higher (lower) than the actual one. Using the Poincaré-Bendixson theorem, Dafermos (2017) shows that this system can produce cycles. Instability and cycles are more likely when the responsiveness of the propensity to spend to the target debt ratio is high. He also shows that when the target debt ratio is endogenised via a Minsky mechanism, an otherwise stable system can become unstable.

This model is also used to examine the implications of two fiscal rules: (i) a Maastricht-type fiscal rule in which government expenditures decline (increases) when government indebtedness is high (low) and (ii) a Godley-Minsky fiscal rule that is close to the idea of counter-cyclical fiscal policy. The simulation analysis in the paper shows that the Maastricht type fiscal rule is conducive to instability while the Godley-Minsky fiscal rule tends to stabilise the macroeconomy.

Jump et al. (2017) develop a model with heterogeneous firms in which the aggregate target debt ratio is determined by firms' decisions via a switching mechanism. Firms choose between a hedge strategy with a low target debt ratio or a speculative strategy with a high target. The probability that firms select the speculative strategy increases as the interest payments relative to profits decreases and the volatility of output goes down. This implies that good and stable economic and financial performance induces more firms to select the speculative strategy, resulting in a higher aggregate target debt ratio. In the model, a higher target debt ratio affects investment positively (but actual debt negatively). The 3D system of the model consists of output, debt and the proportion of the firms that choose the hedge strategy. This system can produce limit cycles: in a stable growth period firms switch to higher debt targets. The initial equilibrium becomes unstable and leads to a boom. Once volatility increases firms switch back to a hedge strategy. The model can also give rise to chaotic dynamics if firms are allowed to accumulate financial assets.

\subsection{Minsky-Veblen models}

Despite the fact that household debt was not at the core of Minsky's analysis, there are some early Minsky models that have formalised consumer debt using Minskyan ideas (e.g. Palley, 1994, 1997). More recently, the Veblenian analysis of emulation motives has been used in some Minsky models to analyse the dynamics of consumer debt and the implications for financial fragility (Kapeller and 
Schütz, 2014; Ryoo and Kim, 2014; Kapeller et al., 2016). In these models low-income households take on debt in order to emulate the consumption of richer households. ${ }^{13}$

Ryoo and Kim (2014) develop a Kaldorian SFC model with households, firms and banks. Firms make investment expenditures by using equity and undistributed profits to finance their investment (they do not take out loans). There are two types of households: workers and rentiers. Workers demand consumer credit in order to increase their consumption and emulate the consumption of rentiers. Banks provide loans to workers taking into account their net income. Rentiers consume part of their income and wealth and do not take on debt. The 2D system of the model comprises the debt-tocapital ratio and the emulation motive. With this system cycles may emerge (the authors use the Poincaré-Bendixson theorem to show that). When the indebtedness of workers is sufficiently low, workers are more willing to take on debt in order to emulate the rentiers and, simultaneously, banks are more willing to provide these loans. This increases the debt-to-capital ratio which has feedback effects into the emulation: workers have to pay a higher interest that reduces their income and increases the income of rentiers. This reinforces the consumption differential between workers and rentiers producing a further rise in the debt-to-capital ratio. Once the debt ratio has reached a sufficiently high level, workers become less willing to take on more debt and banks become less accommodative. Note that instability and cycles are more likely when banks' decision to provide loans is more accommodating and workers' decision to emulate the rentiers is sufficiently strong.

Kapeller and Schütz (2014) develop a large scale SFC model that consists of firms, households and banks. There are three main differences between the model of Kapeller and Schütz (2014) and Ryoo and Kim (2014). First, Kapeller and Schütz (2014) incorporate three types of households instead of two: (i) type 1 worker households whose income share is constant; (ii) type 2 worker households whose income share is declining; (iii) rentiers. Emulation refers only to the intra-worker consumption: it is assumed that type 2 workers try to emulate the consumption of type 1 workers and the consumption of rentiers does not affect the consumption of workers. Second, in similar lines with Charles (2008), Kapeller and Schütz (2014) assume an endogenous interest rate which is a positive function of debt. Third, bankruptcy is introduced. Workers become bankrupt when they cannot cover their subsistence-level consumption. When this happens, banks' expectations are adversely affected and credit supply goes down.

In their simulations, Kapeller and Schütz (2014) produce cycles. Initially, the decline in the income of type 2 worker households relative to the income of type 1 worker households leads to an increase in their indebtedness which also leads to an increase in the interest rate. However, at some point in time the rise in indebtedness causes bankruptcies that stop credit expansion leading to a decline in economic activity. After some periods the economy recovers because bankruptcies reduce the debt of type 2 worker households, increasing their income.

Kapeller et al. (2016) extend the model developed by Kapeller and Schütz (2014) by introducing the role of fiscal policy and a more active banking sector. In their simulations they investigate the effects

${ }^{13}$ Charpe et al. (2009) develop a Minskyan model with a Goodwin-type labour market in which workers take on debt in order to increase their consumption expenditures. The model is similar to the Minsky-Veblen models in that consumption expenditures are driving the financial dynamics and household debt is key. However, loans are solely determined by the fact that workers have an exogenous marginal propensity to consume which is larger than one and there is no explicit mechanism through which they emulate the consumption norms of richer households. 
of various government interventions (such as fiscal stimulus and bank bailouts) and financial regulation on the financial cycles. They show that the government interventions mitigate the impact of financial crises but they shorten the time between the crises since they are conducive to higher credit expansion. The financial crises become much less severe when a stricter financial regulation (captured by a higher responsiveness of credit availability to the leverage of banks) is implemented.

Overall, in the Minsky-Veblen models consumer debt is the driver of financial fragility. Credit expansion depends positively on inequality and the financial soundness of households. Financial booms come to an end when the interest payments of households have become sufficiently high. The endogeneity of the interest rate is not necessary in order to get financial cycles.

\section{Asset price dynamics}

The models described in the previous sections do not allow a role for asset price dynamics. This is at odds with Minsky's analysis according to which asset inflation positively affects investment and economic activity (see, for example, his 'two price' theory of investment). Actually, most Minskyan models that were developed in late 1980s and early 1990s paid particular attention to the role of asset prices. This changed after mid 1990s where most authors started developing Minskyan models using the Kaleckian framework where asset prices do not play a key role. ${ }^{14}$ However, since 2010 there has been a resurgence of interest in Minsky models with asset prices. It is also interesting that the asset price Minsky models have traditionally confined their attention to equity prices - real estate prices have only very recently been combined with Minskyan dynamics.

\subsection{Equity price Minsky models}

The equity price Minsky models place particular attention on the equity price dynamics and their interactions with the real economy. In these models there is an equity market and households take portfolio decisions that affect the demand for equity and thus the equity price, which in turn affects economic activity through consumption or investment. Equity market is the principal source of instability and both cycles and instability are investigated.

Taylor and O'Connell (1985) developed the first model that formalised Minsky's arguments and put equity prices at the core of the analysis. Their model economy consists of firms, households and a government. Banks are not explicitly considered. Firms issue equity in order to finance their investment expenditures. There are two types of households: workers who consume all of their income and rentiers who invest in three different assets: equity, money and government bonds. Money is exogenous and the interest rate changes endogenously.

Firms' desired investment rate depends on the actual rate of profit $(r)$, a confidence variable that captures the difference between the expected and the actual rate of profit $(\rho)$ and the interest rate $(i)$ :

\footnotetext{
${ }^{14}$ There are many SFC models that were developed in 2000s and analysed the interactions between asset prices, the leverage of firms and the real economy (e.g. Lavoie and Godley, 2001-2; van Treeck, 2009). However, most of these models do not examine explicitly Minskyan dynamics.
} 


$$
g d=\alpha+\zeta(r+\rho-i)
$$

where $\zeta$ is the responsiveness of firms' investment to the expected difference between profit and interest costs. The variable $\rho$ plays a key role in the model since it captures the role of expectations. When expectations improve, $\rho$ increases, having a positive impact on the investment rate. Its law of motion is given by:

$$
\dot{\rho}=-\xi(i-\bar{i})
$$

According to equation (20), expectations improve when the interest rate is lower than a normal interest rate, $\bar{i}$. The dynamics of the model rely on the interaction between $\rho$ and money. Suppose that there is an exogenous increase in the confidence of firms. Higher confidence has two countervailing effects on the interest rate. On the one hand, improved expectations increase investment and economic activity causing a rise in the interest rate via the traditional IS-LM mechanism. On the other hand, a higher expected rate of profit shifts wealth from money into equity. This reduction in the demand for money tends to reduce the interest rate. If the first effect dominates, the system converges towards its fixed point after some damped oscillations because the model assumes a negative effect of the interest rate on expected profitability. If the second effect dominates, the system becomes unstable. This is more likely when there is high asset substitution.

Franke and Semmler (1989) extended the model of Taylor and O'Connell (1985) by including firm loans. Net borrowing increases when $\rho$ becomes higher and the debt-to-capital ratio becomes lower. The underlying assumption is that banks take into account both the expected gross profitability and the indebtedness of the firms when they decide about the provision of loans. There are no government bonds and households choose only between two assets: equities and deposits. The debt-to-capital ratio takes values between zero and one. When the debt ratio is equal to one the risk of bankruptcy is at its maximum level and hence no further lending and borrowing can take place. This introduces a boundedness in the system. The change in $\rho$ is a positive function of the difference between the rate of profit and the interest rate and a negative function of the debt-tocapital ratio. Overall, their model produces a dynamic interaction between $\rho$ and the debt-tocapital ratio. This dynamic interaction can give rise to stability or cycles depending on the responsiveness of the law of motion of the debt-to-capital ratio to itself and $\rho$.

Delli Gatti and Gallegati (1990) develop a model which has many similarities with the model of Taylor and O'Connell (1985) but differ primarily in the way that the investment function and the portfolio choice are formalised. Firms invest taking into account their retained profits and the difference between asset prices and the price of investment goods. By using such an investment specification, the authors formalise the 'two price' theory of investment of Minsky. Interestingly, it is assumed that the sensitivity of investment to profits increases during the business cycle (however, they do not include an explicit equation for that). The rationale for this pro-cyclical sensitivity is that during expansion firms' profits increase and as a result both firms and banks consider that the projects are less risky and thereby investment relative to profits becomes higher. Households consume part of their income. Their demand for money depends on the transaction motive, the speculative motive and the finance motive. The demand for finance is equal to the financing gap: the difference between investment and retained profits. There is implicitly a portfolio choice between 
equity and money. The authors use the leverage ratio as an indicator of financial fragility. The leverage ratio is defined as the ratio between the financing gap and retained profits.

The 2D system of the model consists of the profits of firms and the price of equity. The change in profits is determined by the difference between investment and saving (the IS curve) while the law of motion of equity prices is obtained by the difference between the supply and the demand for money (the LM curve). The model can produce various dynamics depending on the relative strength of the different effects. They pay particular attention to the case in which profits, leverage and equity prices move hand in hand during the ascending phase of the business cycle.

Delli Gatti et al. (1994) extended the model of Delli Gatti and Gallegatti (1990). They made two key changes. First, they included an explicit portfolio choice between equity and money. The demand for each asset depends on the expected rates of return. Second, they incorporated an equation in which the propensity to invest out of profits is a positive function of output. The model can produce cycles that behave as follows. During the ascending phase of the business cycle the propensity to invest out of profits increases. As a result, investment and output become higher, increasing external finance and debt. At the same time, since economic activity increases dividends, investors decide to increase their holdings in equity and the price equity gradually improves. This equity price inflation boosts investment. However, at some point, internal funds do not increase sufficiently compared to debt commitments. At this point we have a recession in which investment, output and the price of equity become lower. As a result, the propensity to invest with respect to profits gradually becomes lower. This produces a larger drop in investment and economic activity exacerbating the recession. Economic activity starts increasing again when debt commitments have been reduced sufficiently compared to profits.

More recently, Ryoo (2010, 2013a) developed an equity price Minsky model that builds on the above-mentioned models. There are five key differences: (i) asset prices affect economic activity not only via investment but also via consumption; (ii) money is assumed to be determined endogenously and the interest rate is exogenous; (iii) the interaction between the portfolio choice and debt dynamics is modelled more explicitly and the role of capital gains is taken into account; (iv) the model pays particular attention to stock-flow consistency; $(v)$ a distinction is made between short cycles and long waves.

Ryoo's (2010, 2013a) model consists of households, firms and banks. Contrary to Ryoo (2013b), the equity-to-deposits ratio is not constant: the demand for equities increases when the return on equity becomes higher than the interest rate on deposits. Investment expenditures are financed via retained profits, banks loans and equities. Loans are assumed to increase when the profitability of firms improves; contrary to Ryoo (2013b), the availability of credit does not depend on the financial position of banks. As in Ryoo (2013b), equity issue acts as the residual source of finance for firms.

Ryoo (2013a) has developed a Kaleckian and a Kaldorian version of his model. In the Kaleckian version the goods market is stable as in the Kalecki-Minsky models and capacity utilisation is allowed to fluctuate. Investment is debt-led. This comes from the fact that (i) loans are equal to deposits and, as a result, a rise in loans leads to a rise in the wealth and the interest income of households, boosting consumption and (ii) investment depends only on capacity utilisation and not on the rate of profit, which means that the interest payments of firms have no effect on investment. Ryoo shows 
that in such a Kaleckian model the portfolio decisions of households can produce a cyclical behaviour.

Let us now focus on the Kaldorian version of the model. As in Ryoo (2013b), the Kaldorian version distinguishes between short cycles and long waves. The short cycles are Kaldorian real cycles while the long waves refer to financial cycles. The system that produces the long waves consists of three state variables: the equity-to-deposits ratio, the expected rate of return on equity and the debt-tocapital ratio.

In the long run actual capacity utilisation is equal to the exogenously given desired one $(\bar{u})$. The household wealth-to-capital ratio is given by $\left(p_{e} e+M\right) / K$, where $p_{e}$ is the price of equities, $e$ is the number of equities and $M$ denotes deposits. Since in the model $D=M$ (i.e. loans are equal to deposits), we have that the household wealth-to-capital ratio is equivalent to the Tobin's q. Tobin's q can be written as a function of the equity-to-deposits ratio $\left(a=p_{e} e / D\right)$ and debt-to-capital ratio:

$q=\frac{p_{e} e+D}{K}=(1+a) d$

Tobin's q could be incorporated in the Kaleckian investment function in order to get a direct link between asset prices and investment. However, this would not change the essence of the dynamic analysis (Ryoo, 2013a, p. 49).

Households' consumption depends on disposable income and wealth. Using a linear specification, we have:

$\frac{C}{K}=c_{1} y_{d}+c_{2} q$

where $y_{d}$ is the disposable income of households (equal to wages, dividends and interest on deposits), $c_{1}$ and $c_{2}$ are positive parameters.

The ratio of equity-to-deposits $(a)$ and the expected rate of return on equity $\left(\rho^{e}\right)$ change according to the following equations:

$$
\begin{aligned}
& \dot{a}=\kappa\left(\eta\left(\rho^{e}-i\right)-a\right) \\
& \dot{\rho}_{e}=\psi\left(\rho-\rho_{e}\right)
\end{aligned}
$$

where $\rho$ is the (actual) rate of return on equity, $\kappa$ and $\psi$ are positive parameters and $\eta$ is a positive non-linear function of the expected rate of return on equity (i.e. $\partial \eta / \partial \rho e>0$ ). Equation (23) shows that households desired equity-to-deposits ratio, $\eta\left(\rho^{e}-i\right)$, is higher the higher is the expected rate of return on equity compared to the interest rate on deposits. The equity-to-deposits ratio increases when the desired one is higher than actual one. Equation (24) implies that the expected rate of return on equity changes via an adaptive expectations mechanism whereby the expected rate of return on equity increases when the actual rate of return is higher than the expected one. From equations (23) and (24) we can derive the evolution of the price of equities. Ryoo (2013a) mentions that these equations can be viewed as a reduced form of the interactions between fundamentalists and chartists that are analysed in the behavioural finance literature but 
gives otherwise little explanation for these key equations that drive the cycle. Equations (23) and (24) can be derived from a momentum trader model where momentum traders (or chartists) and fundamentalists co-exist (Beja and Goldman, 1980). Fundamentalists expect the price to return to its fundamental value (thus the negative effect of $a$ on $\dot{a}$ ), whereas the momentum traders expect a further increase in prices when asset price growth exceed expected capital gains (equation 24).

The debt-to-capital ratio increases as the profit-interest ratio becomes higher. According to Ryoo (2013a) the profit-interest ratio captures the fundamental margins of safety. Therefore, when this ratio becomes higher firms are more willing to take on more debt and banks are more willing to expand credit. Thus debt also changes endogenously over the cycle, it plays a role in transmitting the cycle to the real sector and interacts with asset prices; however, it is not essential for the cycle itself.

Ryoo (2013a) shows that closed orbits or explosive oscillations will occur if the impact of momentum traders $(\partial \eta / \partial \rho e)$ is sufficiently large. The cycles in the model can be explained as follows. Suppose that initially the expected rate of return is sufficiently high. As a result, households increase their demand for equity. The higher the demand for equity the higher their price. This higher price increases the capital gains on equity and consequently the actual rate of return on equity. Since households have adaptive expectations about the expected rate of return on equity, the higher the actual rate of return the higher the expected rate of return on equity and, hence, the higher their demand for equity (i.e. the chartists dominate price formation). The equity-to-deposits ratio cannot increase continuously since there is imperfect asset substitution (households always wish to keep some deposits in their portfolio) and since households take into account the 'fundamentals'. As a result, the increase in the equity-to-deposits ratio becomes small as the expected rate of return in equity is too high. Hence, the demand for equities and the return on equity gradually start declining. This asset price deflation process does not continue forever again because of the reference to the 'fundamentals' and imperfect asset substitution. The new cycle begins when the expected rate of return starts increasing and becomes sufficiently high so as to induce a new rise in the equity-todeposits ratio. These dynamics of the model resemble the dynamics of Taylor and O'Connell (1985) in the case where there is high asset substitution and as a result the system becomes unstable.

Chiarella and Di Guilmi (2011) propose a heterogeneous agents model that builds on and extends Taylor and O'Connell (1985) in several ways. On the financial side they allow investors to hold equity, debt and money as financial assets. They distinguish between two groups of firms, those with debt (called speculative firms) and those without debt (referred to as hedge firms). Firms invest depending on their equity price, which in turn depends on the expectations of future returns (demand or debt obligations have no impact on investment). These returns are determined by the composition of financial market actors. Chiarella and Di Guilmi (2011) distinguish between chartists and fundamentalists, whose relative shares are determined stochastically. Their use of the terms chartists and fundamentalists differ somewhat from the literature. Chartists value speculative firms highly (but do not base evaluation on past experience) and fundamentalists value debt-free firms highly (but this valuation is not based on a fundamental value as conventionally defined). A high share of chartists drives up the prices of speculative firm equity; a high share of fundamentalists drives up the price of hedge firm equities. Equity prices are the result of idiosyncratic shocks and the share of chartists. Equity prices drive investment. Firms produce with fixed coefficient production function (and infinitely elastic labour) and sell their output with a fixed mark-up. If profits fall below debt obligations, the firm goes bankrupt. New firms enter as a positive function of output growth. 
The model is discussed analytically by a mean-field analysis and simulated numerically. Chiarella and Di Guilmi (2011) report that the model matches firm stylised facts in terms of firm distributions and it exhibits cycles in output, equity prices, debt and bankruptcies.

To sum up, in the equity price Minsky models the portfolio decision of households is introduced in order to analyse the destabilising role of the equity market. This portfolio decision does not exist in most debt or interest dynamics models. Households allocate their wealth between different assets, for example, between equity and deposits (Franke and Semmler, 1989; Ryoo, 2010, 2013a), between equity and money (Delli Gatti and Gallegati, 1990) or between equity, money and government bonds (Taylor and O'Connell, 1985), taking into account the relative rate of return of each asset. Instability and cycles typically emerge when households invest more in the equity market and as a result the rate of return on equity improves, inducing a further rise in the demand for equities. Ryoo (2010, 2013a) and Chiarella and Di Guilmi (2011) introduce speculative dynamics by (explicitly or implicitly) distinguishing between fundamentalists and noise traders. This has feedback effects on economic activity since the resulting higher equity prices affect positively investment (via Tobin's q or expectations) or consumption (via the wealth effect). There are some equity price Minsky models that have equity as residual source of finance (e.g. Ryoo, 2010, 2013a) and others where debt act as a residual (e.g. Chiarella and Di Guilmi, 2011).

\subsection{Real estate price Minsky models}

The real estate price Minsky models analyse housing debt, paying particular attention to the interaction between housing prices and collateral. The key real estate price Minsky model has been developed by Ryoo (2016). ${ }^{15}$ Housing prices in this model play a similar role as the stock prices in the equity price Minsky models. Firms finance their investment expenditures by issuing equity and by using their internal funds. They do not take out corporate debt. There are two types of households: workers and rentiers. Workers take on mortgages and invest in the housing market while rentier households invest in equities and deposits as in Ryoo (2013a). Banks provide mortgages to worker households taking into account their collateral (i.e. there is explicit credit rationing).

Following Ryoo (2010, 2013a, 2013b), Ryoo (2016) makes again a distinction between Kaldorian short cycles and financial long waves. The long waves are captured by a 3D system in which the state variables are workers' housing wealth-to-capital ratio, the expected rate of return on houses and household debt-to-capital ratio. The housing wealth-to-capital ratio of workers $\left(h_{w}\right)$ and the expected rate of return on houses $\left(\mu_{e}\right)$ change according to the following equations:

$$
\begin{aligned}
& \dot{h}_{w}=\kappa\left(\eta(\mu e-i) c w-h_{w}\right) \\
& \dot{\mu}_{e}=\psi\left(\mu-\mu_{e}\right)
\end{aligned}
$$

where $c w$ is workers' household consumption-to-capital ratio, $\mu$ is the (actual) rate of return on housing and $\eta$ is a positive non-linear function of the expected rate of return on housing (i.e.

\footnotetext{
${ }^{15}$ Zezza (2008) develops an SFC model with housing prices. However, he does not take explicitly into account Minskyan dynamics.
} 
$\partial \eta / \partial \mu e>0)$. Equation (25) shows that workers' desired housing wealth-to-consumption ratio, $\eta(\mu e-i)$, is higher the higher is the expected rate of return on housing, $\mu e$, compared to the interest rate on deposits (which is constant). The housing wealth-to-capital ratio increases when the desired housing wealth-to-capital ratio is higher than the actual wealth-to-capital ratio. Equation (26) shows that the expected rate of return on housing changes via an adaptive expectations mechanism. The third state variable of the 3D system, the debt-to-capital ratio, is positively affected by workers' household net income and their net worth.

In this system instability is more likely when credit supply is highly responsive to the value of collateral, the sensitivity of housing supply to prices is low and the demand for houses is highly sensitive to expected capital gains. The cycles produced are similar to the cycles in the equity price Minsky models. Note that even with a constant debt-to-capital ratio it is possible to get cycles in the $h_{w}$ and $\mu$ e space. In this case the cycles can be described as follows. An increase in the expected housing price inflation produces a higher demand for houses. This gives a boost to housing prices and increases the actual rate of return on houses. Similarly to the equity price Minsky models, worker households have adaptive expectations about the expected rate of return on houses. As a result, the higher the actual rate of return on houses the higher the expected rate of return on houses. This brings about a boost to the demand for houses. At some point, workers' housing wealth-to-capital ratio stops increasing since households do not want to have a housing wealth-toconsumption rate above a specific upper limit. At this point, workers' desired housing wealth-tocapital ratio and the expected rate of return on houses start decreasing. This does not continue forever since households always want to invest a proportion of their net wealth in houses. When $h w$ and $\mu e$ become sufficiently low a new cycle begins where the expected rate of return on houses and workers' housing wealth-to-capital ratio start increasing again.

In the case which the debt-to-capital ratio changes in an endogenous way the increase in housing prices gives a boost to the value of the collateral. The higher the value of the collateral the higher the credit provision by banks. At some point, the debt payment commitments become sufficiently high, decreasing loan expansion and consequently the debt-to-capital ratio.

\section{Mainstream Minsky models}

Recently, there have been several attempts to incorporate Minskyan ideas into mainstream economic frameworks. By mainstream we mean models that insist on explicit microfoundations and, in the area of macroeconomics, use Dynamic Stochastic General Equilibrium (DSGE) models as the key reference point. Bhattacharya et al. (2015) present a model of financial markets where investors can choose between a risky and a safe asset. The payout from these assets depends on whether the economy is in a good or bad state. Investors and bankers update their forecasts based on past experience. In a bad state investors may default on their loans, which results in some deadweight loss. Bankers extend loans and charge interest on it based on the expected default rates and costs. Bhattacharya et al. (2015) demonstrate that competitive market outcomes are suboptimal as investors do not take into account the externalities of their default, i.e. the deadweight loss and the risk premium effects of their defaults, because they are price takers on credit markets. The paper has explicit reference to Minsky and its novelty is in the explicit modelling of defaults. It neither 
demonstrates the existence of endogenous cycles, nor is it concerned with the macroeconomic effects of financial dynamics.

Farmer (2013) incorporates some Minskyan features into a rational expectations model with search of unemployment. His model is a multiple equilibrium model, where a belief function (also referred to as 'animal spirits') allows rational actors to choose between a continuum of possible equilibria. The belief function effectively determines the labour supply of the model and changes in animal spirits are thus transmitted (in proper New Classical fashion) via labour supply shocks. The main strength of the model is that animal spirits shocks have permanent labour market effects. Debt and financial fragility do not play a role in Farmer's model, nor is investment a key variable. Eggertsson and Krugman (2012) build a model with two types of agents, which differ by their rate of time preference. The impatient agents will thus borrow from the patient ones. The model imposes an upper limit to borrowing and the main part of the paper discusses how in the case of an exogenous shock to the borrowing limit, the model exhibits Keynesian features like large multipliers and debt deflation problems. In a large deleveraging shock the AD curve can become upwards sloping and more flexible labour market will mean a larger output reduction. The paper demonstrates that in a deleveraging economy the Keynesian features will be strong; it has a prominent role for debt, but it does not discuss endogenous cycles. The main actors are households, not businesses. Overall these models are attempts to incorporate some of Minsky's arguments in an optimisation framework, but they do not fulfil Minsky's ambition to analyse endogenous real-financial dynamics.

\section{Conclusion}

This paper has suggested a categorisation of Minsky-inspired models. While Minsky had been an obscure economist for much of his life, since the mid 1980s there has been a growing literature on the formalisation of his arguments. This paper has surveyed the existing Minsky models highlighting their key differences and similarities. Our categorisation makes a broad distinction between the models that focus on the dynamics of debt or interest, with no or a secondary role for asset prices, and the models in which asset prices play a key role in the dynamic behaviour of the economy. Within the debt or interest dynamics models debt is typically behaving procyclically and exerts a negative effect on demand. We made a distinction between the Kalecki-Minsky models that assume a stable goods market, the Kaldor-Minsky models which postulate instability in the goods market and the Goodwin-Minsky models that incorporate debt dynamics into the traditional Goodwin interactions between the wage share and employment rate. We also analysed the credit rationing Minsky models, in which credit provision depends on banks' financial position, and the endogenous target debt ratio models, which are driven by the stock-flow norms of the private sector that change endogenously during the economic cycle. The Minsky-Veblen models combine consumer debt with the Veblenian ideas of emulation motives. Unlike the previous models this last group is about household debt rather than corporate debt. Within the asset price models, we distinguished between (i) the equity price Minsky models that analyse the cycles and the instability that arise from the dynamics of equity prices and (ii) the real estate price Minsky models that study the dynamic interaction between mortgages and housing prices.

Our survey has focused on theoretical models, but it is the case that the Minsky literature so far has concentrated on theoretical modelling and there is only a handful of rigorous empirical papers (e.g. 
Schroeder, 2009; Mulligan, 2013; Nishi, 2016; Davis et al., 2017) which often focus on specific mechanisms (such as the pro-cyclical debt ratio) rather than testing the models discussed in this survey. There are three sets of questions that follow from this survey: What are the main points of differences between the Minsky models? Are they complementary or competing? What has been missing in the literature and what are its limitations? What are the implications for future research?

Different authors develop Minsky's arguments in a variety of different ways, both in terms of the key mechanisms involved and in terms of what is to be explained. In particular, some authors are eager to demonstrate that local instability can emerge without paying attention to the global properties of the models, while others want to demonstrate the emergence of endogenous cycles. Both the debt or interest dynamics models and the asset price dynamics models analyse the interaction between the real sector and the financial sector, but one important difference is that the asset price dynamics models can generate pure financial cycles. Moreover, the models covered differ in their investment functions, in the source of residual finance, in the key financial variables that matter and in the sector that is vulnerable to financial fragility. As regards the investment function the distinction between Kaleckian and Kaldorian models is whether investment is overshooting with respect to demand; many of the models discussed have interest payments (or retained earnings) impacting on investment, whereas in the endogenous target debt ratio models investment is affected by the target ratios which capture perceived uncertainty; in asset price dynamics models equity prices have a direct impact on investment. Models also differ on whether debt or equity issue is regarded as the main source of residual finance. Debt dynamics models lend themselves more to credit as the residual source of finance while asset price dynamics may lend themselves to equity as residual source of finance; however there is no one to one pairing. As regards the household debt models, the Minsky-Veblen models and the real estate price models differ on whether consumption emulation or wealth effects are the main drivers of debt accumulation.

What are the limitations of the Minskyan models analysed in this review? A first limitation is that there is no common framework of analysis. Some authors assume away asset prices, other pay scant attention to debt. We do note that the debt or interest dynamics literature has so far not incorporated asset prices explicitly, whereas several of the asset price dynamics models do explicitly model debt. An increasing number of authors does use SFC models and thus are explicit on the links between financial stocks and flows. As of now there are few heterogeneous agents models and those that exist have only weakly developed demand sides. However, for the most part, the different arguments are not necessarily mutually exclusive. While the Kaleckian and the Kaldorian investment functions are mutually exclusive, debt cycles and asset prices cycles are not exclusive, nor are endogenous debt norms and asset price speculation. However, attempts to synthesise the arguments will soon hit the limits of tractability. Thus, to make progress and keep models manageable it will be important to identify which mechanisms matter most in practise or clarify the conditions under which certain models are applicable.

Second, the link between the empirical literature and the theoretical models is loose. The vast majority of the authors make no attempt to estimate econometrically the key equations of their models or to calibrate the models in order to produce the patterns observed in the real data. Also, among the models discussed only Ryoo (2010, 2013a, 2013b, 2016) asks how real cycles and Minsky cycles interact (Ryoo regards the financial cycles as long waves, but argues that business cycles are due to real factors). 
Overall, Minskyans have made substantial progress in developing and formalising Minsky's rich ideas. Future research should make a concerted effort to confront Minsky models with empirical data - both in the sense of testing the different mechanisms and evaluating their relative importance, but also in terms of calibrating the models and clarifying what the periodicity and the amplitude of the cycles is. 


\section{References}

Asada, T. (2001) Nonlinear dynamics of debt and capital: a Post-Keynesian analysis. In Y. Aruka (ed), Evolutionary Controversies in Economics. Tokyo: Springer-Verlag.

Beja, A. and Goldman, M.B. (1980) On the dynamic behaviour of prices in disequilibrium. The Journal of Finance 25: 235-248.

Bernanke, B. and Gertler, M. (1990) Financial fragility and economic performance. The Quarterly Journal of Economics 105 (1): 87-114.

Bhattacharya, S., Goodhart, C.A.E., Tsomocos, D.P., Vardoulakis, A.P. (2015) A reconsideration of Minsky's financial instability hypothesis. Journal of Money, Credit and Banking 47 (5): 931-973.

Charles, S. (2008) Teaching Minsky's financial instability hypothesis: a manageable suggestion. Journal of Post Keynesian Economics 31 (1): 125-138.

(2016) Is Minsky's financial instability hypothesis valid? Cambridge Journal of Economics. 40 (2): 427-436.

Charpe, M., Flaschel, P., Proaño, C. and Semmler, W. (2009) Overconsumption, credit rationing and bailout monetary policy: A Minskyan perspective. European Journal of Economics and Economic Policies: Intervention 6 (2): 247-270.

Chiarella, C. and Di Guilmi, C. (2011) The financial instability hypothesis: a stochastic microfoundation framework. Journal of Economic Dynamics and Control 35 (8): 1151-1171.

Chiarella, C. Flaschel, P., Groh, G. and Semmler, W. (2000) Disequilibrium, Growth and Labor Market Dynamics: Macro Perspectives. Springer.

Dafermos, Y. (2017) Debt cycles, instability and fiscal rules: a Godley-Minsky model. Cambridge Journal of Economics, forthcoming.

Davis, L.E., de Souza J.P.A. and Hernandez, G. (2017) An empirical analysis of Minsky regimes in the US economy. Working Paper 08, UMass Amherst.

Delli Gatti, D. and Gallegati, M. (1990) Financial instability, income distribution, and the stock market. Journal of Post Keynesian Economics 12 (3): 356-374.

Delli Gatti, D., Di Guilmi, C., Gaffeo, E., Giulioni, G., Gallegati, M. and Palestrini, A. (2005) A new approach to business fluctuations: heterogeneous interacting agents, scaling laws and financial fragility. Journal of Economic Behavior and Organization 56: 489-512.

Delli Gatti, D., Gallegati, M. and Gardini, L. (1994) Complex dynamics in a simple macroeconomic model with financing constraints. In G. Dymski and R. Pollin (eds), New Perspectives in Monetary Macroeconomics. University of Michigan.

Delli Gatti, D., Gallegati, M., Giulioni, G. and Palestrini, A. (2003) Financial fragility, patterns of firms' entry and exit and aggregate dynamics. Journal of Economic Behavior and Organization 51: 79-97.

Delli Gatti, D., Gallegati, M., Greenwald, B., Russo, A. and Stiglitz, J.E. (2010) The financial accelerator in an evolving credit network. Journal of Economic Dynamics and Control 34: 1627-1650.

Dutt, A.K. (1995) Internal finance and monopoly power in capitalist economies: a reformulation of Steindl's growth model. Metroeconomica 46 (1): 16-34.

Eggertsson, G. and Krugman, P. (2012) Debt deleveraging, and the liquidity trap: a Fisher-Minsky-Koo approach. The Quarterly Journal of Economics 127 (3): 1469-1513.

Farmer, R. (2013) Animal spirits, financial crises and persistent unemployment. Economic Journal 123: 317-340.

Fazzari, S., Ferri, P. and Greenberg, E. (2008) Cash flow, investment, and Keynes-Minsky cycles. Journal of Economic Behavior and Organization 65 (3-4): 555-572.

Foley, D. (1987) Liquidity-profit rate cycles in a capitalist economy. Journal of Economic Behavior and Organization 8 (3): 363-376.

- (2003) Financial fragility in developing economies. In A. Dutt and J. Ros (eds), Development Economics and Structuralist Macroeconomics. Edward Elgar. 
Franke, R., Semmler, W. (1989) Debt financing of firms, stability, and cycles in a dynamical macroeconomic growth cycle. In W. Semmler (ed), Financial Dynamics and Business Cycles, M.E Sharpe.

Godley, W. (1999) Seven unsustainable processes: medium-term prospects and policies for the United States and the world, Special Report, Levy Economics Institute of Bard College.

Goodwin, R.M. (1951) The non linear accelerator and the persistence of business cycles. Econometrica 19 (1): 1-16.

- (1967) A growth cycle. In C.H. Feinstein (ed), Socialism, Capitalism and Growth. Cambridge, UK: Cambridge University Press.

Grasselli, M.R. and Costa Lima, B. (2012) An analysis of the Keen model for credit expansion, asset price bubbles and financial fragility. Mathematical Financial Economics 6 (3): 191-210.

Greenwald, B. and Stiglitz, J. (1993) Financial market imperfections and business cycles. The Quarterly Journal of Economics 108 (1): 77-114.

IMF (2012) World Economic Outlook April 2012. Washington: IMF.

Jarsulic, M. (1989) Endogenous credit and endogenous business cycles. Journal of Post Keynesian Economics 12 (1): 35-48.

(1990) Debt and macro stability. Eastern Economic Journal 16 (2): 91-100.

Jump, R.C., Michell, J. and Stockhammer, E. (2017) A strategy switching approach to Minskyan business cycles, manuscript.

Kaldor, N. (1940) A model of the trade cycle. Economic Journal 50 (197): 78-92.

Kalecki, M. (1937) The principle of increasing risk. Economica 4 (16): 440-44.

Kapeller, J. and Schütz, B. (2014) Conspicuous consumption, inequality and debt: the nature of consumption-driven profit-led regimes. Metroeconomica 66(1): 51-70.

Kapeller, J., Landesmann, M., Mohr, F.X. and Schütz, B. (2016) Government policies and financial crises: mitigation, postponement or prevention? The Vienna Institute for International Economic Studies Working Paper 126.

Keen, S. (1995) Finance and economic breakdown modelling Minsky's 'financial instability hypothesis'. Journal of Post Keynesian Economics 17: 607-635.

-- (2013) A monetary Minsky model of the Great Moderation and the Great Recession. Journal of Economic Behavior and Organization 86: 221-235.

Lavoie, M. (1995) Interest rates in Post-Keynesian models of growth and distribution. Metroeconomica 46 (2): 146-177.

(2014) Post-Keynesian Economics: New Foundations. Cheltenham, UK and Northampton, MA, USA: Edward Elgar.

Lavoie, M. and Godley, W. (2001-2). Kaleckian models of growth in a coherent stock-flow monetary framework: a Kaldorian view. Journal of Post Keynesian Economics 24 (2): 277-312.

Lavoie, M. and Seccareccia, M. (2001) Minsky's financial fragility hypothesis: a missing macroeconomic link? In P. Ferri and R. Bellofiore (eds), Financial Fragility and Investment in the Capitalist Economy: The Economic Legacy of Hyman Minsky, Vol. 2. Cheltenham: Edward Elgar.

Le Heron, E. and Mouakil, T. (2008) A Post-Keynesian stock-flow consistent model for dynamic analysis of monetary policy shock on banking behaviour. Metroeconomica 59 (3): 405-440.

Lima G. and Meirelles A. (2007) Macrodynamics of debt regimes, financial instability and growth. Cambridge Journal of Economics 31: 563-580.

Minsky, H.P. (1975) John Maynard Keynes. New York: Columbia University Press.

------- (1982) Inflation, Recession and Economic Policy. M.E. Sharpe.

(2008) [1986] Stabilizing an Unstable Economy. New Haven: Yale University Press.

Mulligan, R. (2013) A sectoral analysis of the financial instability hypothesis. The Quarterly Review of Economics and Finance 53 (4): 450-459.

Nikolaidi, M. (2014) Margins of safety and instability in a macrodynamic model with Minskyan insights. Structural Change and Economic Dynamics 31: 1-16. 
Nishi, H. (2012) A dynamic analysis of debt-led and debt-burdened growth regimes with Minskian financial structure. Metroeconomica 63 (4): 634-660.

(2016) An empirical contribution to Minsky's financial fragility: evidence from non-financial sectors in Japan, Kyoto University, Graduate School of Economics Discussion Paper Series E-16007.

Palley, T.I. (1994) Debt, aggregate demand, and the business cycle: an analysis in the spirit of Kaldor and Minsky. Journal of Post Keynesian Economics 16 (3): 371-390.

(1997) Endogenous money and the business cycle. Journal of Economics 65 (2): 133-149.

Ryoo, S. (2010) Long waves and short cycles in a model of endogenous financial fragility. Journal of Economic Behaviour and Organization 74 (3): 163-186.

- (2013a) Minsky cycles in Keynesian models of growth and distribution. Review of Keynesian Economics 1 (1): 37-60.

(2013b) Bank profitability, leverage and financial instability: a Minsky-Harrod model. Cambridge Journal of Economics 37 (5): 1127-1160.

----- (2016) Household debt and housing bubble: a Minskian approach to boom-bust cycles. Journal of Evolutionary Economics 26: 971-1006.

Ryoo, S. and Kim, Y.K. (2014) Income distribution, consumer debt and keeping up with the Joneses. Metroeconomica 65 (4): 585-618.

Sasaki, H. and Fujita, S. (2012) The importance of the retention ratio in a Kaleckian model with debt accumulation. Metroeconomica 63 (3): 417-428.

Schroeder, S. (2009) Defining and detecting financial fragility: New Zealand's experience. International Journal of Social Economics 36 (3): 287-307.

Semmler, W. (1987) A macroeconomic limit cycle with financial perturbations. Journal of Economic Behavior and Organisation 8: 469-95.

Skott, P. (1989) Conflict and Effective Demand in Economic Growth. Cambridge University Press, Cambridge.

(1994) On the modeling of systemic financial fragility. In A. Dutt (ed): New Directions in Analytical Political Economy. Aldershot: Edward Elgar.

Sordi, S. and Vercelli, A. (2014) Unemployment, income distribution and debt-financed investment in a growth cycle model. Journal of Economic Dynamics and Control 48: 325-348.

Stockhammer, E. and Michell, J. (2017) Pseudo-Goodwin cycles in a Minsky Model. Cambridge Journal of Economics 41 (1): 105-125.

Taylor, L. and O'Connell, S.A. (1985) A Minsky crisis. Quarterly Journal of Economics 100 (Supplement): 871-885.

van Treeck, T. (2009) A synthetic, stock-flow consistent macroeconomic model of 'financialization'. Cambridge Journal of Economics 33 (3): 467-493.

Veblen, T. (1970) [1899] The Theory of the Leisure Class. London: Allen and Unwin.

White, W. (2009) Modern macroeconomics is on the wrong track. Finance and Development 46 (4): 15-18.

Zezza, G. (2008) U.S. growth, the housing market, and the distribution of income. Journal of Post Keynesian Economics 30 (3): 375-401. 
Figure 1. Families of Minsky models

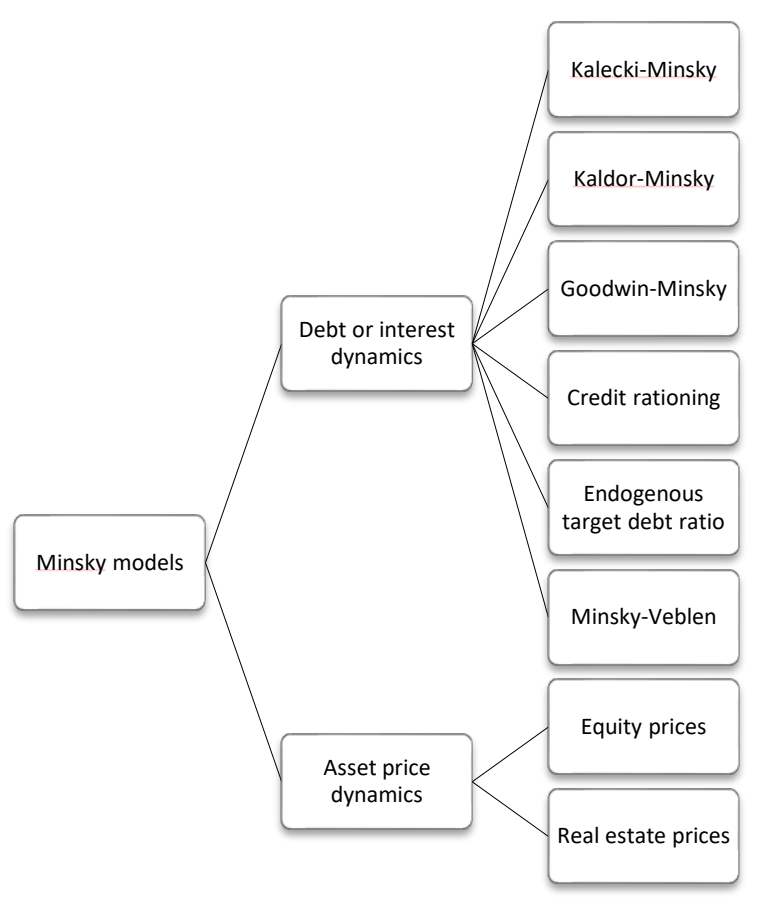


Table 1. Key differences and similarities between the families of Minsky models

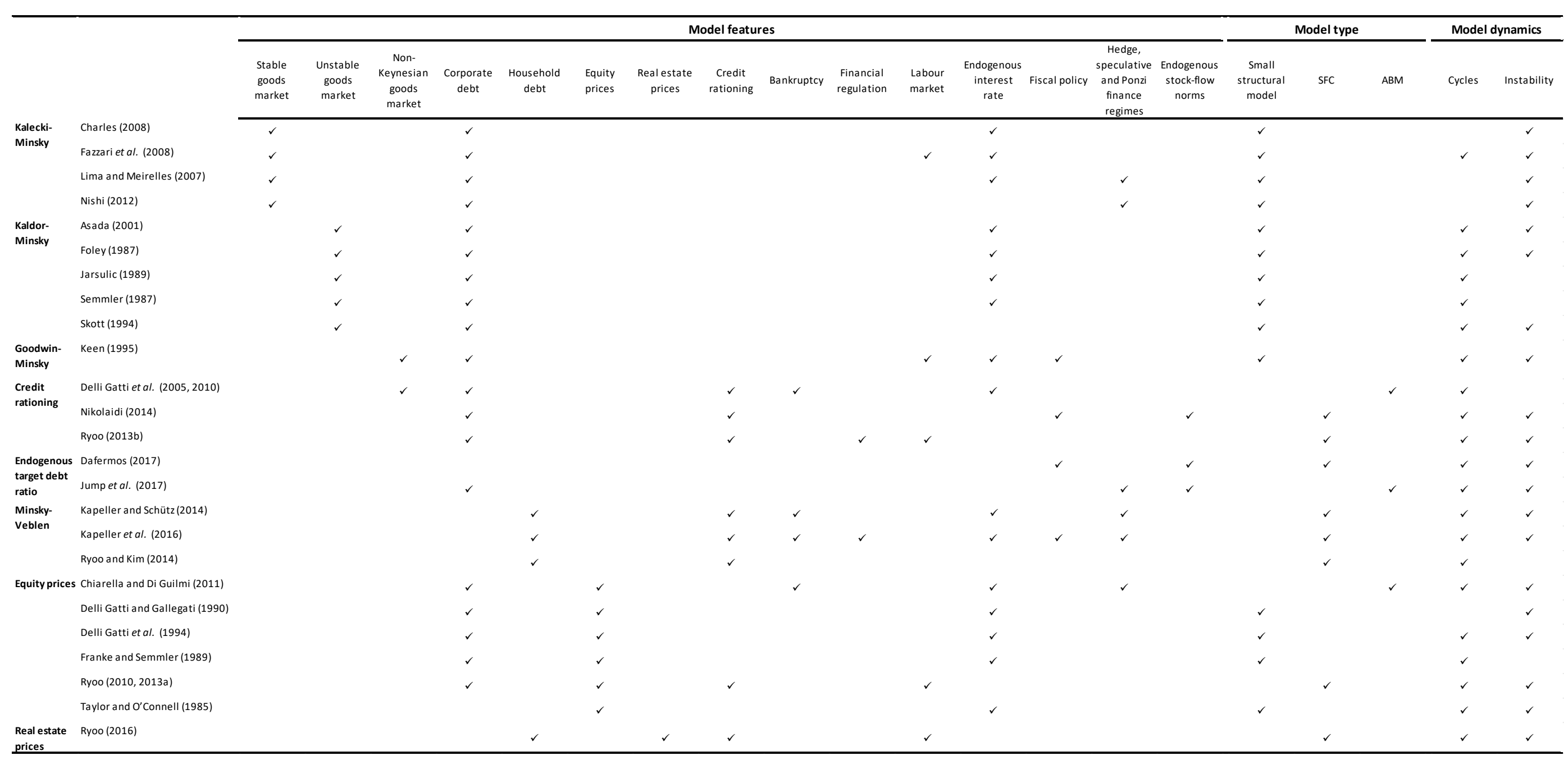

